\title{
Protist (Ciliates) and Related Diseases
}

\author{
Dhikra Souidenne and Hidetaka Furuya
}

\begin{abstract}
Ciliates are one of the most common protistan parasites in cephalopods. In this chapter, we have undertaken to describe the biology and diversity of parasitic ciliates in European cephalopods and give diagnosis elements to identify the known species. We briefly summarize available data on the ciliates parasitizing the gills and skin of European cephalodops (Ancistrocomidae) and the endoparasitic forms observed in the digestive tract and renal appendages (Opalinopsidae). Ancistrocomidae ectoparasites have been observed in Octopus vulgaris. Opalinosidae family harbours two parasitic genera: Opalinopsis and Chromidina. Species diversity of these two genera seems to be underestimated in Europe.
\end{abstract}

Keywords

Parasitic ciliates $\cdot$ Opalinopsidae $\cdot$ Opalinopsis $・$ Chromidina $・$ Ancistrocomidae

\subsection{Introduction}

Ciliates are one of the most frequently encountered protistan parasites in cephalopods. In addition to the endoparasitic forms observed in the digestive tract, ciliates have been described as ectoparasites parasitizing the gills and skin of different cephalopods.

D. Souidenne $(\bowtie)$

Muséum National d'Histoire Naturelle de Paris, Biologie Des Organismes et Ecosystèmes Aquatiques (BOREA), Research

Group: Reproduction and Development, Evolution, Adaptation, Regulation, CNRS 7208, Sorbonne Université, UCN, IRD 207, 43 rue Cuvier, Paris, France

e-mail: dhikra.souidenne@mnhn.fr

H. Furuya

Department of Biology, Graduate School of Science, Osaka

University, Toyonaka, Osaka 560-0043, Japan

e-mail: hfuruya@bio.sci.osaka-u.ac.jp

\subsection{Ancistrocomidae (Chatton and Lwoff 1931)}

Ancistrocomidae ciliates have been described parasitizing skin and gills of Octopus bimaculoides (Forsythee and Hanlon 1991). In European cephalopods they have been identified in Octopus vulgaris parasitizing gills (Fig. 10.1) with a high prevalence, and in some occasions the skin. However, no Ancistrocomidae parasites have been observed in Sepia officinalis.

Free living and attached forms can be observed, measuring $17-25 \mu \mathrm{m}$ in length and showing oval or pyriform shaped, with a large centrally located nucleus and a food vacuole in the distal end of the body. Fresh preparations show that the ciliation pattern typically surrounds all the body. Histologically submucosal inflammatory infiltrates producing bronchitis were observed in heavily parasitizied octopus. 
Fig. 10.1 Ancistrocomidae ciliates parasitizing the gills of O. vulgaris. a-b General aspect of gills infected by the ciliates showing free living and anchored forms. c-d Detail of the gill epithelium where anchored ciliates with pyriform shape and large centrally located nucleus are observed. a-d: H\&E. Scale bars a $200 \mu \mathrm{m} ; \mathbf{b} 200 \mu \mathrm{m} ; \mathbf{c} 100 \mu \mathrm{m}$; d $20 \mu \mathrm{m}$ (pictures courtesy of Dr. C. Gestal)
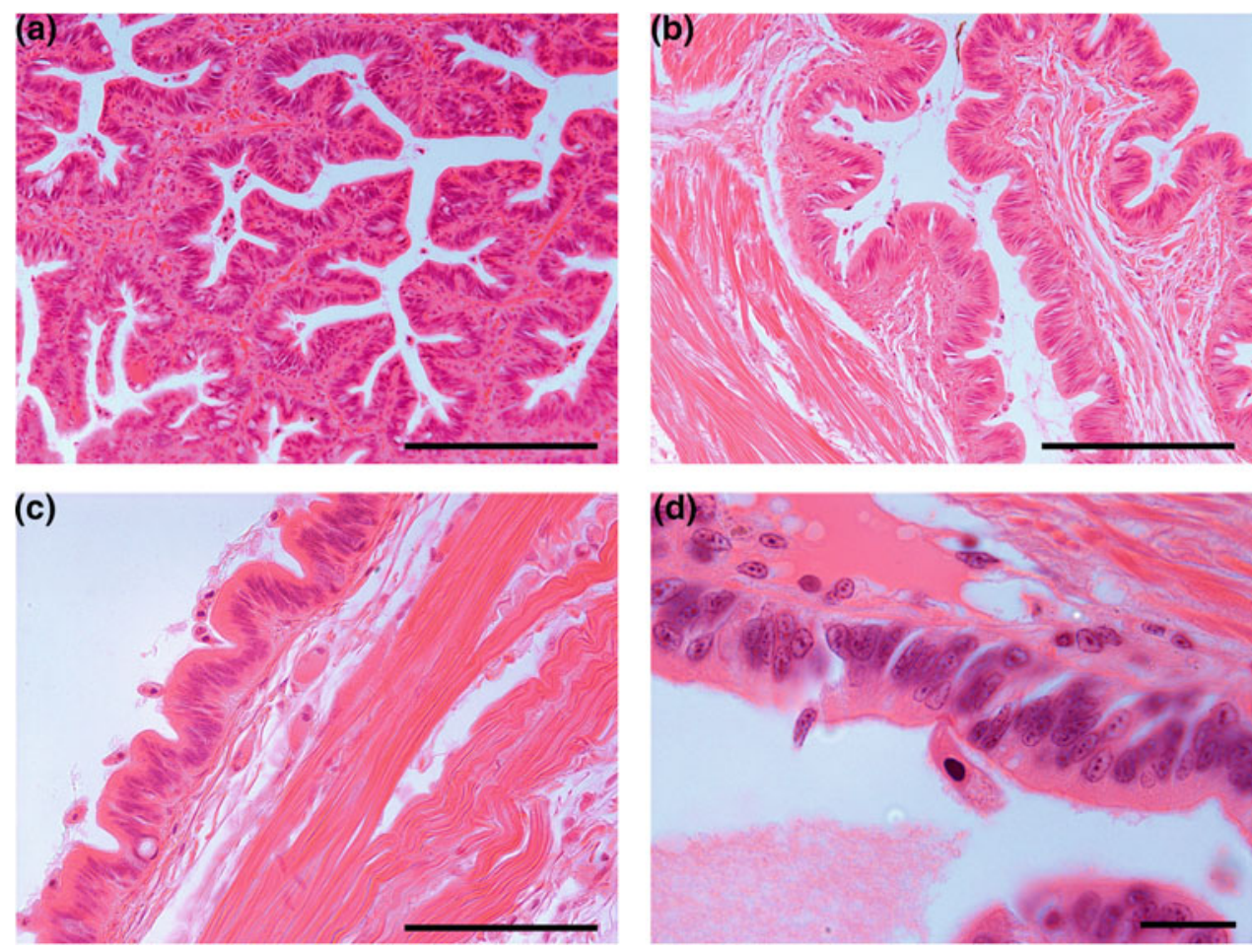

\subsection{Opalinopsidae Hartog (1906) (Synonyms: Chromidinida, Chromidinidae)}

Although cephalopods and fishes share a wide range of parasite groups that can infest both of them, only one family of parasites, Opalinopsidae Hartog (1906) (synonyms to Chromidinida, Chromidinidae), is restricted to cephalopods and can never infect fishes.

Opalinopsidae are, after the dicyemids, the most common parasites in cephalopods. Their classification is mainly based on their morphology. Gonder (1905) and Dobell (1908) initially described the Apostomes Opalinopsidae as holotrichious protistan parasites of cephalopods.

The macronucleus of Opalinopsidae is a complex, continuous network distributed in parasite body. Regarding a mode of reproduction, there are two ways of interpretation: Foettinger (1881) believed budding is a multiplication mode in Opalinopsidae, while Dobell (1908) regarded it as a segmentation. In most of Opalinopsidae, developmental stages are very labile and sensitive to seawater. Their reproduction mode and complete life cycle remains to be determined. In addition, molecular data still needed to confirm the monophyly of the Opalinopsidae family.
Foettinger (1881) and Dobell (1908) distinguished two genera

- parasites of the renal appendages of cephalopods: Chromidina Gonder (1905)

- parasite of the liver and intestine of cephalopods: Opalinopsis Foettinger (1881).

Main differences between the two genera are summarized in the table below (Table 10.1):

\subsubsection{Opalinopsis, Parasites of the Liver of Cephalopods, in Europe}

Parasites of the genus Opalinopsis are restricted to the digestive tract of cephalopods. The only study to avoid repetition of Opalinopsis in Europe was reported by Foettinger (1881), who gave detailed description for these parasites. Later, Chatton and Lwoff $(1931,1935)$ studied Opalinopsis by analogy to Chromidina in order to evaluate their distinctive criteria. To date, only two species of Opalinopsis were described and named by Foettinger (1881). The following descriptions are bibliographical synthesis between Foettinger (1881), Dobell (1909), Chatton 
Table 10.1 Characteristic differences of Opalinopsis and Chromidina

\begin{tabular}{|c|c|c|}
\hline & Opalinopsis & Chromidina \\
\hline $\begin{array}{l}\text { Number of } \\
\text { morpho-species } \\
\text { described }\end{array}$ & 2 & 6 \\
\hline \multicolumn{3}{|c|}{ Common characteristics } \\
\hline Ciliature & \multicolumn{2}{|l|}{ Holotrichious, helicoidal ciliature, very dense } \\
\hline Nucleus & \multicolumn{2}{|c|}{ Fragmented nucleus, highly crosslinked, dissociated in uniform masses, spherical or vesiculous } \\
\hline \multicolumn{3}{|c|}{ Distinctive characteristics } \\
\hline Shape & Ovoid & Vermiform \\
\hline Microhabitat & Liver and intestine of cephalopods & Renal organs of cephalopods \\
\hline Host habitat & Benthic, mesopelagic cephalopods & Pelagic and mesopelagic cephalopods \\
\hline Mouth & No mouth observed & $\begin{array}{l}\text { Oral blank for tomite stages but no } \\
\text { buccal cavity }\end{array}$ \\
\hline Nutrition & Diffusion & $\begin{array}{l}\text { Eat renal cells when attached to the } \\
\text { renal appendages or feed by diffusion } \\
\text { when free in the urine }\end{array}$ \\
\hline Host (genus) & Alloteuthis, Heteroteuthis, Histioteuthis, Sepia, Sepietta, Sepiola, Octopus & Widely in cephalopod genera \\
\hline Mobility & $\begin{array}{l}\text { Free in the liver or fixed massively to the epithelium of the hepatic channels } \\
\text { and the intestine by their anterior widened end characterized by } \\
\text { distinguishable papillum, kinetie ciliature and infraciliature }\end{array}$ & $\begin{array}{l}\text { Attached their anterior end to the renal } \\
\text { epithelium, but detached individuals } \\
\text { can swim in the urine. }\end{array}$ \\
\hline Kinetie & With gaps & Without gaps \\
\hline Vacuole & Presence of a contractile vacuole in the posterior end & Present only for the tomite stage \\
\hline Macronucleus & Macronucleus organized as a network in the medulla zone & $\begin{array}{l}\text { Macronucleus organized as a network } \\
\text { throughout the cell }\end{array}$ \\
\hline Micronucleus & Unique micronucleus with ellipsoidal shape & Unique micronucleus streamlined shape \\
\hline Number of kineties & $\begin{array}{l}30 \text { kineties never reaching neither the anterior end nor the posterior end } \\
\text { (both ends are bare) }\end{array}$ & 12-14 kineties \\
\hline Trichocyst & Absent & Present \\
\hline Multiplication & Equatorial split & $\begin{array}{l}\text { Division of the distal region in several } \\
\text { segments. Each segment develops into } \\
\text { the adult stage }\end{array}$ \\
\hline Physiology & Survives for a long time in sea water & Die in the presence of sea water \\
\hline
\end{tabular}

and Lwoff (1931, 1935), Hochberg (1971, 1982, 1983, 1990) and Souidenne et al. (2016) descriptions and author's observations on the liver of freshly fished cephalopods.

\subsubsection{Opalinopsis sepiolae (Foettinger 1881)}

$O$. sepiolae is a parasite of the liver of Sepiola rondeletti in the gulf of Naples. Foettinger reported the infection $17 \%$ of examined hosts and, if present, these ciliates are very dense.

Bodies are ovoid, covered with short vibrative cilia, and have a pointed or round big anterior extremity. The size ranges $60-120 \mu \mathrm{m}$ length and 30-62 $\mu \mathrm{m}$ width near the anterior end, and 30-44 $\mu \mathrm{m}$ at the posterior end (from the smallest specimens to the biggest specimens). Mobile specimens always have their anterior end in their swimming direction. The trophotomont is attached to its microhabitat (liver/intestine) by a rostrum (Hochberg 1971). Cytostome, rosette or oral cilia are lacked (Foettinger 1881; Gonder 1905; Dobell 1909; Hochberg 1971).

Kineties are oblique and forming a curved radiation, widely spaced, starting from the central part of the body and have gaps at some parts (Foettinger 1881; Chatton and Lwoff 1935).

A fragmented nucleus is observed in a few live specimens. This type of nucleus is dissociated in small fragments, which can be relinked together in a single nucleus afterward.

Generally, the nucleus has network shape; small nuclei linked in a spread, spherical aspect or in sticks shape.

Multiplication of $O$. sepiolae is mainly by transversal segmentation of the body. The division plane results that 
posterior half is shorter that the anterior half. However, Foettinger (1881) observed just once, two individuals conjugation marked by the fusion of the two bodies followed a traversal division. The survivals in sea water probably can leave the host and swim in the water to infect a new host. However, the complete life cycle and the transmission of the infection mode are still unkown.

\subsubsection{Opalinopsis octopi (Foettinger 1881)}

Foettinger (1881) has observed $O$. octopi for the first time when he examined Octopus tetracirrhus (Delle Chiaje 1830) and later it was found in Octopus macropus by Hochberg (1971).

$O$. octopi has been obtained from $O$. tetracirrhus (Foettinger 1881; Gonder 1905; Hochberg 1971) in Naples (Italy) and Banyuls (France) (Foettinger 1881; Hochberg 1990).

Today, there is no solid proof that $O$. octopi differs from O. sepiolae. The only difference is the host species (Foettinger 1881). It needs to be confirmed that Opalinopsis has host specificity.

\subsubsection{Chromidina in Europe}

Apostome ciliates, Chromidina Gonder (1905), inhabit in the renal sacs of pelagic cephalopods, while the dicyemids infect mainly the benthic cephalopods (Furuya et al. 2004). They are specific to this microhabitat because they feed from cephalopod tissues and fluids (Hochberg 1971; Souidenne et al. 2016). They have a characteristic nuclear system 'a chromidial system'. Chromidina species were reported in 25 cephalopod species. Today, only six species of Chromidina have been described (Souidenne et al. 2016).

\section{- Life cycle}

A hypothetical life cycle was deduced from the different development stages observed and the existence of a crustacean intermediate host was suggested by analogy to other apostomes. The adult stage, unlike the other apostomes, is vermiforme and called trophotomont. It can reach $2 \mathrm{~mm}$ length. When the trophotomont is extended posteriorly with only one long bud, the budding process is called monotomy. Later, this bud will develop into a vermiform adult identical to the founder trophotomont. When the trophotomont is extended posteriorly with a chain of small ciliated buds or tomite, the budding process is called palintomy. Tomite stage is probably in charge of the transmission of the infection from a host to another (Landers 2010; Souidenne et al. 2016).

\section{- Diversity in Europe}

Only two species of Chromidina have been reported in Europe.

\subsubsection{Chromidina elegans Foettinger (1881) (Synonym: Benedenia elegans)}

C. elegans have been first described in Naples by Foettinger (1881) from the renal appendages of Sepia elegans d'Orbigny, 1825. Chatton and Lwoff (1935) redescribed this species from cuttlefishes from Banyuls-sur-Mer, France. $C$. elegans can also infect Sepia orbignyana Ferussac, 1826, Illex coindetti Vérany, 1837; Todarodes sagittatus Lamarck, 1798 and Octopus salutii Vérany, 1839 in France and England (Hochberg 1971, 1982, 1983). There is no available information about the prevalence of this Chromidina species.

C. elegans is considered to be a typical species of the genus Chromidina and this is reason why it was redescribed by Chatton and Lwoff (1935) and Souidenne et al. (2016).

The trophotomont is vermiform, that reaches $1.4 \mathrm{~mm}$ length. It is easily distinguishable from other Chromidina by its club-like apex and 14 Kineties (Collin 1915; Chatton and Lwoff 1935; Souidenne et al. 2016).

Occasionally, some trophotomonts of C. elegans grow rapidly and extend up to $5 \mathrm{~mm}$ length and they become hypertrophonts.

\subsubsection{Chromidina coronata}

C. coronata was described from $O$. vulgaris by Foettinger (1881), then, from Eledone cirrhosa by Gonder (1905), and from Illex coindetii by Dobell (1909). Foettinger (1881) did not mention the prevalence or mean intensity, but described the dense condition in the renal appendages when parasites were present. $C$. coronata is very similar to $C$. elegans in body length, body shape, nuclear aspect. However, $C$. coronate is easily distinguishable from $C$. elegans and the other Chromidina species by the claviform apex and the crown of long cilia surrounding the anterior end.

\subsection{Concluding Remarks}

Chromidina ciliates are host-specific to the pelagic squids and octopus. However, they are found occasionally in benthic or epibenthic cephalopods when these hosts have a pelagic development stage: like E. cirrhosa, O. salutii, Scaeurgus unicirrhus ... implying that they can encounter Chromidina (typically present in the water column, avoiding competition with dicyemids present near the seabed and infecting the benthic cephalopods).

The monophyly of Chromidina is supported among Oligohymenophorea, Apostomatia, Astomatophorida (Souidenne et al. 2006). However, molecular information of Opalinopsis is not available, thus, its phylogenetic position is unclear. The molecular data are essential to clear the relationship between Opalinopsis and Chromidina and to support the monopholy of the Opalinopsidae family. 


\section{life cycle of Chromidina}

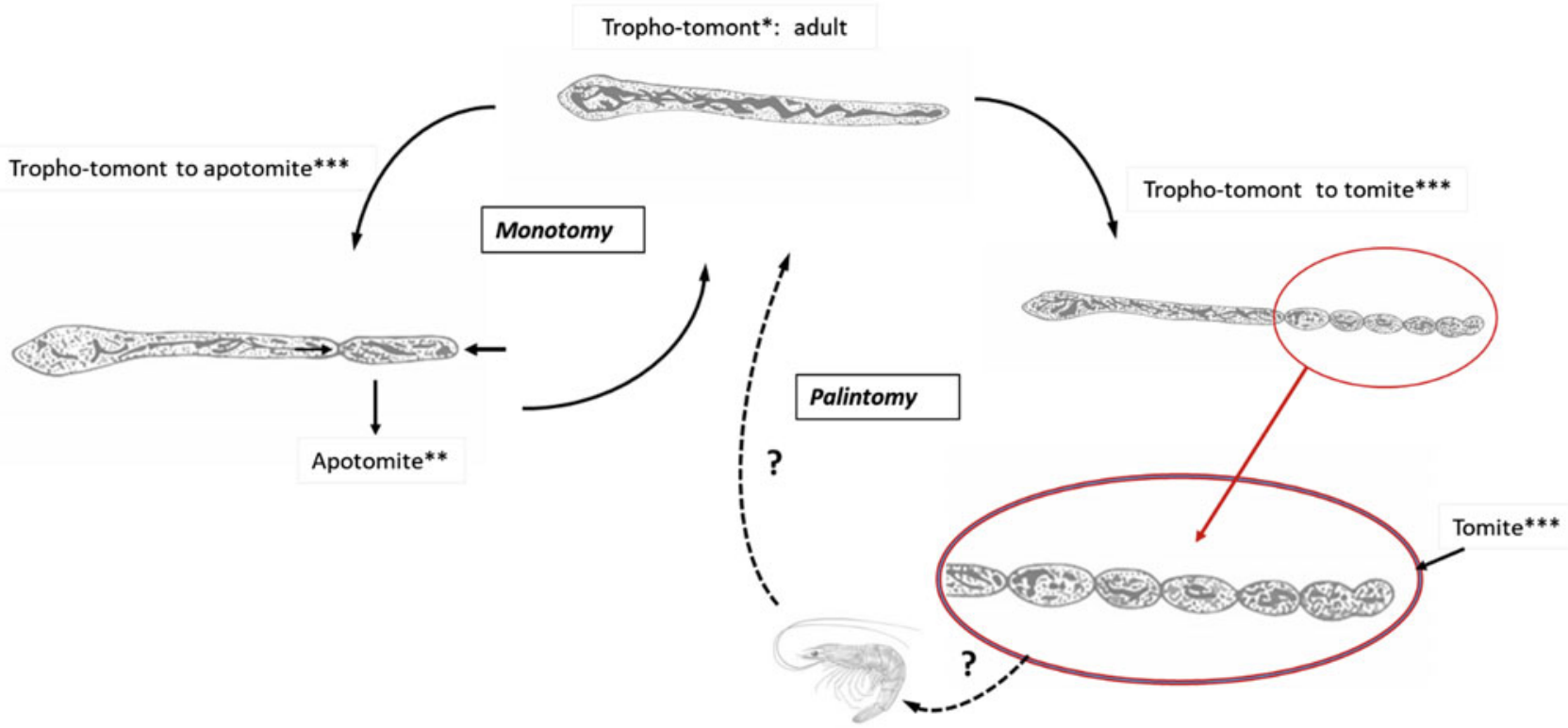

* Trophotomont : vermiform adult of Chromidina, devoloped from an apotomite

** Apotomite: long bud, result of tropho-tomont monotomy

*** Tomite: small bud, result of tropho-tomont palintomy, forming a chain

Fig. 10.2 Life cycle of the Chromidina (modified from Furuya et al. 2004; on C. elegans, modified from Foettinger 1881)

Table 10.2 Summary of Opalinopsidae parasites of European cephalopods

\begin{tabular}{|c|c|c|c|c|}
\hline $\begin{array}{l}\text { Ciliate } \\
\text { parasite of } \\
\text { cephalopods }\end{array}$ & $\begin{array}{l}\text { Microhabitat } \\
\text { of the } \\
\text { parasite }\end{array}$ & Host species & Locality & Author(s) \\
\hline \multirow{4}{*}{ O. sepiolae } & \multirow{4}{*}{ Liver } & Rossia macrosoma & Norway (Atlantic Ocean) & \multirow[t]{3}{*}{ Hochberg (1971) } \\
\hline & & Sepietta oweniana & France (Mediterranean) & \\
\hline & & Sepiola atlantica & England (English channel) & \\
\hline & & Sepiola rondeletii & Italy, Monaco, France & $\begin{array}{l}\text { Foettinger (1881); Gonder (1905); Dobell } \\
\text { (1909); Collin (1915); Chatton and Lwoff } \\
\text { (1935) }\end{array}$ \\
\hline \multirow[t]{2}{*}{ O. octopi } & \multirow[t]{2}{*}{ Liver } & O. macropus & Italy (Mediterranean) & Hochberg (1971) \\
\hline & & O. tetracirrhus & Italy (Mediterranean) & $\begin{array}{l}\text { Foettinger (1881); Gonder (1905); Hochberg } \\
\text { (1971) }\end{array}$ \\
\hline C. elegans & $\begin{array}{l}\text { Renal } \\
\text { appendages }\end{array}$ & $\begin{array}{l}\text { S. elegans, } S . \\
\text { orbignyana, } I . \text { coindetti, } \\
\text { T. sagittatus, } O \text {. salutii }\end{array}$ & $\begin{array}{l}\text { Italy, France } \\
\text { (Mediterranean Sea, } \\
\text { Banyuls-sur-Mer), England } \\
\text { (English Channel) }\end{array}$ & $\begin{array}{l}\text { Foettinger (1881); Gonder (1905); Dobell } \\
\text { (1909); Collin (1915); Chatton and Lwoff } \\
\text { (1935); Hochberg (1971); Souidenne et al. } \\
\text { (2016) }\end{array}$ \\
\hline C. coronata & & $\begin{array}{l}\text { O. vulgaris, E. cirrhosa, } \\
\text { Sepiola rondeleti, } S . \\
\text { unicirrhus, Illex } \\
\text { coindetti }\end{array}$ & $\begin{array}{l}\text { Italy, France } \\
\text { (Mediterranean Sea, } \\
\text { Banyuls-sur-Mer), England } \\
\text { (English Channel) }\end{array}$ & $\begin{array}{l}\text { Foettinger (1881); Dobell (1909); Chatton and } \\
\text { Lwoff (1935); Hochberg (1971); Souidenne } \\
\text { et al. (2016) }\end{array}$ \\
\hline
\end{tabular}


To date, only eight species of Opalinopsidae have been described, and only four have been reported in Europe. This suggests that the diversity of Opalinopsiadae is underestimated.

Their impacts on their host individuals are still unknown. Some authors suggest that they may be a symbiont (Hochberg 1990; Furuya et al. 2004; Souidenne et al. 2006). Further studies on these enigmatic ciliates are needed to understand the host-parasite relationship (Fig. 10.2 and Table 10.2).

\section{References}

Chatton E, Lwoff A (1928) Sur la structure, l'évolution et les affinités des Opalinopsides (Ciliés) des Céphalopodes. C R Hebd Acad Sci, Paris 186:1382-1384

Chatton E, Lwoff A (1931) La conception des Ciliés Apostomes (Foettingériidés+Opalinopsidés). Preuve de sa valdité. C R Hebd Acad Sci, Paris 193:1483-1485

Chatton E, Lwoff A (1935) Les ciliés apostomes 1. Aperçu historique et général; étude monographique des genres et des espèces. Arch Zool Exp Gen. 77:1-453

Collin B (1915) A propos de Chromidina elegans (Foettinger). C R Hebd Acad Sci 160:406-408

Dobell CC (1908) The structure and life-history of Copromonas subtilis n. g., n. so.: a contribution to our knowledge of the Flagellata. Quart J Micr Sci 52:75-120
Dobell CC (1909) Some observations on the infusoria parasitic in Cephalopoda. Q il microsc Sci 53:183-199

Foettinger A (1881) Recherches sur quelques Infusoires nouveaux parasites des Céphalopodes. Arch Biol 2:345-378

Furuya H, Ota M, Kimura R, Tsuneki K (2004) Renal organs of cephalopods: a habitat for dicyemids and chromidinids. J Morphol 262(2):629-643

Gonder R (1905) Beiträge zur Kenntnis der Kernverhältnisse bei den in Cephalopoden schmarotzenden Infusorien. Arch Protis 5:240-262

Hartog M (1906) Protozoa. In: Harmer SF, Shipley AE (eds) The Cambridge natural history, vol 1. pp 1-162

Hochberg FG (1971) Some aspects of the biology of cephalopod kidney parasites. Ph.D. dissertation, University of California, Santa Barbara

Hochberg FG (1982) The 'kidneys' of cephalopods: a unique habitat for parasites. Malacologia 23:121-134

Hochberg FG (1983) The parasite of cephalopods: a review. Mem Nat Mus Vict, Melbourne 44:109-145

Hochberg FG (1990) Diseases caused by protistans and mesozoans. In: Kinne O (ed) Diseases of marine animals, vol III, Biologische Anstalt Helgoland: Hamburg, Germany, pp 47-227

Landers SC (2010) The fine structure of the tropho-tomont of the parasitic apostome Chromidina (Ciliophora, Apostomatida). Protistol 6(4):271-279

Souidenne D, Florent I, Dellinger M, Justine JL, Romdhane MS, Furuya H, Grellier P (2016) Diversity of apostome ciliates, Chromidina spp. (Oligohymenophorea, Opalinopsidae), parasites of cephalopods of the Mediterranean Sea. Parasite 23:33
Open Access This chapter is licensed under the terms of the Creative Commons Attribution 4.0 International License (http://creative commons.org/licenses/by/4.0/), which permits use, sharing, adaptation, distribution and reproduction in any medium or format, as long as you give appropriate credit to the original author(s) and the source, provide a link to the Creative Commons licence and indicate if changes were made.
The images or other third party material in this chapter are included in the chapter's Creative Commons licence, unless indicated otherwise in a credit line to the material. If material is not included in the chapter's Creative Commons licence and your intended use is not permitted by statutory regulation or exceeds the permitted use, you will need to obtain permission directly from the copyright holder. 